\title{
ПСИХОЛОГО - ПЕДАГОГІЧНА ІНТЕГРАЦІЯ ДІТЕЙ У ДОШКІЛЬНИЙ ЗАКЛАДІ ІЗ СІМЕЙ ВНУТРІШНЬО ПЕРЕМІЩЕНИХ ОСІБ
}

УдК: 159.9.- 051

\section{Мельничук Тетяна Іванівна}

Кандидат психологічних наук, старший науковий співробітник лабораторії організачійної та сочіальної психології Інституту психологї імені Г. С. Костюка Національної академї педагогічних наук Украӥни, м. Київ (Украӥна)

\section{Лосева Ольга Василівна}

Директор дитячого Центру «ILMALINNA», психолог, педагог раннього розвитку, м. Київ (Украӥна)

\begin{abstract}
Анотація. У статті проаналізовано та представлено теоретичний та практичний аналіз процесу інтеграції $i$ адаптації дітей із внутрішньо переміщених сімей до дошкільних закладів. Розглянуто та визначено сучасні погляди щодо ролі впливу сімейного виховання, як системи взаємопов'язаних процесів, щчо навчають $i$ соичіалізують особистість у дитинстві в стресовій ситуачії. Виділено найбільш ефективні психолого профілактичні та соціалізуючи практики для інтеграції дітей у нове сочіально-оточуюче середовище після перенесених травмуючи подій. Зроблено висновки та сформовано перспективи подальших наукових досліджень.

Ключові слова: соичіально-психологічна робота, адаптація дітей 3 внутрипереміщених сімей, соціалізація дитини дошкільного віку, сімейне виховання, інтеграція дошкільників, сочіалізуючи практики.
\end{abstract}

\section{Постановка проблеми та її зв'язок 3} важливими практичними завданнями. Актуальність дослідження психолого - педагогічна інтеграція дітей у дошкільний закладі із сімей внутрішньо переміщених осіб зумовлена необхідністю більш повного аналізу вже існуючого наукового матеріалу для врахування особливостей адаптаційного періоду дітей та пошуку шляхів як адаптації так і подальшої реабілітації дітей з сімей вимушено переміщених осіб, а також їх подальшої інтеграції у нове соціальне середовище.

Історично склалося, що сім'я є одним із перших та найважливіших соціальних інститутів, який дає дитині основний життєвий досвід, забезпечує середовище формування та 
розвитку особистості. Другим важливим інститутом інтеграції дитини у соціалізуючий простір є навчально-виховні заклади, зокрема і дошкільні.

Ситуація, яка склалася останнім часом в Україні - анексія Криму, війна на Сході спричинила появі значної кількості сімей вимушених переселенців, біженців із зони бойових дій.

За даними Агентства ООН у справах біженців, станом вже на 1 вересня 2014 року кількість внутрішньо переміщених осіб в Україні сягнула 259,471 тис. осіб. Також у звіті організації зазначається, що 243,896 тис. осіб внутрішніх переселенців походять зі східних областей України, а 15,845 тис. осіб - з Криму. Сьогодення ще більш лячн, оскільки кількість переселенців збільшилася у рази [7, с. $26]$.

Третина всіх сімей внутрішньо переміщених осіб виховує дітей дошкільного віку. I ці діти пережили значні психотравмуючі події, наслідки які ще довго будуть відбиватися на їхньому фізичному та психічному здоров'ї, поведінці, здатності будувати конструктивні соціальні зв'язки. Значна кількість малюків потребує особливого догляду та піклування, допомоги з боку дорослих, розуміння однолітків. Тому завдання із забезпечення комфортного перебування таких дітей в умовах дитячого садочка покладається в першу чергу на вихователів, практичного психолога, однак без розуміння і допомоги з боку їх сім’ї жод- на психолого-педагогічна робота чи корекційна не буде достатньо ефективною, адже їі має підтримувати загальна атмосфера всього соціалізуючого простору дитини, в тому числі i сім'я. Водночас у світовій та вітчизняній психології не проводилось досліджень, присвячених вивченню специфічних особливостей розвитку та виховання дітей дошкільного віку 3 родин учасників АТО і ВПО. Зокрема, недостатньо вивчені особливості перебігу психологічної травми, її наслідки, особливості формування посттравматичного симптомокомплексу, механізми активізації психологічних захистів на етапі дошкільного дитинства. У психологічній науці не встановлено оптимізуючі ресурси особистості, що допомагають подолати психологічну травму такого характеру та вибудовувати гармонійну картину світу.

Тому наше дослідження орієнтоване на здійсненні теоретичного аналізу наукових джерел і соціалізуючих передових практик щодо процесу інтеграції та адаптації дітей, із внутрішньо переміщених осіб до дошкільних закладів.

Метою статті $\epsilon$ розгляд та теоретичний аналіз наукових джерел і практик процесу інтеграції та адаптації дітей, із внутрішньо переміщених осіб до дошкільних закладів. Виділення найбільш ефективних психологічно профілактичних та соціалізуючих практик для такої інтеграції дітей у дошкільний заклад.

Аналіз останніх досліджень і публіка-

цій. Враховуючи не досить тривалий час, що 
триває в Україні із збільшення значної кількості внутрішньо переміщених осіб, проблема досить актуально досліджується.

Так, соціально-педагогічну та психологічну роботу з дітьми у конфліктний та постконфліктний період досліджують Н. Бочкор, Є. Дубровська, В. Залеська, Н. Пророк, С. Гончаренко, Л. Кондратенко та ін.

Також, сучасні наукові дослідження, розкривають теоретичні основи соціальнопедагогічної роботи 3 дітьми та молоддю (I. Звєрєва, А. Капська, Г. Лактіонова, Л. Міщик, Л. Штефан, С. Гіль, С. Вершловський, Ю. Поліщук, А. Рижанова, С. Харченко); вивчають соціальнопедагогічну діяльність із сім'єю в контексті соціальної роботи (Дж. Баріс, I. Грига, В. Гуров), психолого-педагогічне забезпечення соціальної роботи (В. Торохтій, Б. Хубієв); розкривають засади діяльності сімейного соціального педагога з акцентом на допомозі сім’ї у вихованні дітей (Ф. Кевля, Т. Лодкіна, Г. Селевко); дослідники приділяють увагу окремим напрямам соціально-педагогічної та психологічної роботи 3 сім'єю - опіки над дітьми (С. Бадора, Г. Бевз, Г. Іващенко, Н. Комарова, Т. Мельничук, Ю. Удовенко, Д. Мажец, С. Найдьонова, I. Пєша), наданні психологічної допомоги при роботі у кризових ситуаціях 3 внутрішньо переміщеними особами (Н. Веселова, 3. Кісарчук, Я. Омельчанко, Г. Лазос, Л. Ціренко та ін.), психологічний супровід становлення дошкільної зрілості дитини (Т. Піроженко, С. Ладивір та ін.), питанням теорії, методик виховання і розвитку дітей дошкільного віку присвятили свої праці Л. В. Артемова, Л. І Зайцева, С. А. Козлова, T. I Поніманська, I. П. Рогальська. Пріоритетні напрями досліджень: соціально-моральний розвиток особистості дитини дошкільного віку (I. В. Зубрицька-Макота, С. І. Заболоцька, O. I. Кошелівська, О. I Кисельова, Скрипник Н. І. [3], С. Фасолько, Т. І. Поніманська, I. П. Рогальська). Зарубіжними та вітчизняними психологами здійснено вагомий внесок у дослідження проблем стресу та психологічних травм у дорослих та дітей дошкільного віку (М. Буянов, О. Захаров, В. Панок, Н. Пезешкіан, С. Сельє, Т. Титаренко). Ці та інші автори грунтовно вивчали питання виникнення страхів та тривожності у дітей, емоційних розладів, прояву агресивності та жорстокості, замкненості. Вченими розроблено систему ефективних психотерапевтичних занять 3 використанням казкотерапії, арттерапії, музикотерапії (І. Вачков, Г. Вебер, І. Кучера, Н. Пезешкіан, К. Шеффлер, Б. Хеллінгер). Розроблено та обгрунтовано систему ключових положень щодо консультування батьків $з$ метою оптимізації стилю родинного виховання (I. Бех, О. Кононко, Ю. Приходько, Н. Ньюкомб).

\section{Виклад основного матеріалу і резуль-} татів дослідження.

Однією із рис сьогодення в Україні $\epsilon$ стан абсолютної невпевненості і не прогнозованості. Значна кількість сімей, що стали ви- 
мушеними переселенцями не розуміють, що 3 ними буде відбуватися надалі. Вони не знають, чи вони повернуться за певний час додому, чи будуть вимушені переїхати ще в якесь інше місце. І навіть сім'ї, які вже мають стабільну роботу на новому місці переселення, мають постійне житло, тобто, орієнтовані на остаточний переїзд і знаходять для цього всі можливості, через отриману травму втратили можливість довіряти новому соціальному простору.

Ряд науковців, зокрема Веселова Н. П., провівши аналіз останніх досліджень відмічає, що наразі в Україні немає навіть усталеного терміну, який використовується щодо громадян України, які вимушено тимчасово виїхали із своїх домівок у інші області країни. Так, у літературних джерелах і офіційних документах, у повсякденній мові фахівців трапляються різні визначення цієї категорії осіб: тимчасово переселені особи, внутрішньо переміщені особи (ВПО), переселенці, вимушені мігранти, внутрішні біженці тощо.

Науковці Інституту психології імені Г. С. Костюка у своїх дослідженнях відмітили, що внутрішньо переміщеними особами вважаються люди, змушені залишити свої домівки (місця проживання) для того, щоб уникнути наслідків збройного конфлікту (ситуації загального насилля, порушень прав людини) або стихійних лих чи техногенних катастроф, які не перетнули визнаний на міжнародному рівні державний кордон країни $[1,4,7]$.
На наш погляд, для сьогодення, дуже актуальним $є$ питання дослідження та розроблення як соціальних, так психологопедагогічних заходів для психологічного супроводу та вироблення толерантного ставлення до власних (внутрішніх) мігрантів, а також подолання проблеми мігрантофобії. Вивчення ж досвіду західних фахівців, які давно працюють 3 проблемами мігрантів та біженців, показує, що окрім психологічної підтримки, допомога їм передбачає асиміляцію в нових культурних умовах та адаптацію до незвичних умов життя $[8,9,10]$. Тому доречним у цьому контексті, також, буде окреслити коло функцій психологів, залучених до роботи з сім'ями переселенців, адже психолог виконує на сам перед функцію посередника між культурами і допомагає як мігрантам інтегруватися до нового соціального середовища, так і соціальному середовищі прийняти нових членів.

Тому, провідною складовою при допомозі сім'ям $з$ дітьми, які опинилися в складних життєвих обставинах є забезпечення процесу соціально-психологічної реабілітації всієї родини (сім'ї), враховуючи відповідно, їх індивідуальні потреби, перенесені травмуючи події що сприятиме їх соціальній адаптації. Адже однією із найважливіших систем взаємопов'язаних процесів, що виховують, навчають і соціалізують особистість - $є$ сім'я. У сім’ї дитина отримує перші уявлення про себе та інших людей, розвиває необхідні для життя соціальні почуття, навички спілкування і спільної дія- 
льності, розуміння про працю та блага від неї. Сім'я, виховуючи та передаючи свій міжпоколінний накоплений досвід, створює передумови для взаємопроникнення із світу дітей у світ дорослих, що є важливим чинником соціалізації особистості. Унікальні виховні можливості сім'ї впливають на людину протягом усього її життя $[1,3,4]$.

Аналізуючи останні публікації можна відмітити, що діти мігрантів інтенсивніше, ніж діти не мігранти відчувають брак спілкування з батьками, та іншими дітьми, сильніше відчувають відторгненість батьками, ізольованість від них. В той же час, для батьків, одним iз перших завдань $є$ знайти житло та необхідну роботу, щоб забезпечити первинні потреби сім'ї, тобто соціалізуватися у нове середовище, при цьому, діти відчувають нестачу уваги та перебувають у надзвичайно чутливому стані, викликаному, окрім названого, зміною середовища та необхідністю ресоціалізації. Тому метою психологічної підтримки цієї категорії дітей має бути допомога, що спрямована на подолання відчуття непотрібності, покинутості, одночасно і страху чогось нового, невпевненості в собі, та інших психічних станів викликаних пережитим досвідом. Діти, особливо дошкільного віку, реагують на батьківський психологічний стан, їх емоції, переживання, навіть на тон спілкування. Стресові стани загострюються у дітей ще і у випадку, коли і у навчально-виховних закладах акцентують у вагу, що діти є мігрантами, переселенцями.
Тому, одним із головних завдань при наданні первинної психологічної допомоги сім'ям та дітям є їх вдала соціальна адаптація. [4].

Під соціальною адаптацією розуміють постійний процес актив-ного пристосування індивіда до умов соціального становища, а також результати цього процесу.

Відомо, що навіть незначні зміни умов життя маленької дитини викликають порушення іiї емоційного стану, сну, апетиту тощо. Саме тому створення умов для успішної адаптації до нового середовища $є$ досить серйозною проблемою, яка хвилює лікарів, психологів, педагогів. Тільки після вдалої адаптації до нового оточення - дитина зможе і інтегруватися у навчально-виховний процес, сприймати засвоєння нового матеріалу тощо. [3].

Впродовж дошкільного дитинства малюк неодноразово реалізує власні адаптаційні можливості - це і прихід до дитячого садка, i перехід із однієї групи в іншу, а потім і в школу. Не потребує доказу той факт, що до дитячого садка дитина повинна приходити 3 прогнозом на адаптацію. Якщо ж прогноз відсутній, його складає лікар дошкільного, закладу разом із психологом. Згідно з прогнозом вони визначають особливості організації режиму, харчування, сну кожної дитини. Саме цими призначеннями бажано керуватися вихователям під час адаптації малюка до умов дошкільного закладу, особливо коли ця адаптація проходить разом із інтеграцією у нове соціальне оточення. 
Звикання дитини до нових умов супроводжується порушенням сну, апетиту, загальним ослабленням організму, негативних емоцій, що передається цілою палітрою плачу від скиглення де ревіння. Супутником негативних емоцій є страх - джерело стресового стану дитини. На жаль, у період адаптації прояв малюком позитивних емоцій є дуже рідкісним явищем. Окрім цього, порушується функціональний стан нервової системи - деякі діти кличуть матір, не можуть заснути тощо, інші - тривалий час перебувають у загальмованому стані, неохоче спілкуються 3 дорослими й однолітками, а іноді зовсім мовчать. Спостерігаються зрушення і в деяких вегетативних реакціях, а саме: втрачається вага, загострюються алергічні реакції, раптово підвищується температура тіла тощо. Досить часто у дітей порушуються вже набуті культурно-гігієнічні навички, знижується імунітет [7].

Дослідники А. Й. Капська, Л. Ф. Сафонова наголошують, що втрату звичного життевого світу і частини себе у ситуації кризи неможливо заповнити лише матеріальною підтримкою, наданням тимчасового житла чи закликом «взяти себе в руки». На думку дослідників формою надання такої допомоги може стати спеціально організований процес - соціально-психологічний супровід кризової особистості у комплексі - соціальної підтримки, психологічної тощо [2,5].

Вищесказане набуває ще більшої зна- чущості, коли йдеться про надання соціальних та психолого - педагогічних послуг сім'ям із дітьми дошкільниками, які опинились у складних життєвих обставинах після зміни місця проживання та перенесення травмуючи подій. У цьому разі надзавданням оцінки є визначення і ресурсів громади у яку перемістилась сім'я, навчально-виховного закладу, а саме: створення сприятливого соціальнопсихологічного клімату в навчально - виховному закладі (психологічна просвіта вихователі, педагогічних працівників, батьків); залучення до надання психологічної допомоги висококваліфікованих фахівців: практичних психологів, соціальних педагогів, психотерапевтів, консультантів ПМПК; забезпечення індивідуальним психологічним супроводом дітей, а при потребі і інших членів їх сім’ї, тощо. Також до роботи з дітьми-мігрантами, особливо, необхідно долучати вчителя-логопеда, який допоможе із постановкою вимови та навичкам спілкування. Вихователям та психологам потрібно розуміти, що робота повинна проводитися з усіма дітьми у групі, де знаходиться дитина - мігрант з метою профілактики негативних явищ в оточуючому середовищі і така робота здійснюватися регулярно.

Відомо, що процес адаптації - це постійний процес, який супроводжує людину впродовж усього життя. Науковці визначають адаптацію як пристосування будови і функцій організму, його органів і клітини до умов середовища, спрямоване на збереження рівноваги. 
Розглянемо основні критерії визначення успішності інтеграції дитини до навчального - виховного закладу, які можуть бути застосовані з урахуванням певних особливостей до адаптації та інтеграції дітей ВПО: когнітивний, поведінковий та емоційні компоненти.

Когнітивний компонент інтеграції та адаптації до навчально-виховного процесу полягає в ознайомленні дітей та їх батьків 3 особливостями організації навчальновиховного процесу у дошкільному закладі, специфікою та особливостями діяльності навчально-виховного закладу (режим, графік занять, форма одягу тощо).

Поведінковий компонент відображає, наскільки дитина зможе дотримуватися вимог, які висуває до нього навчально - виховний заклад (мати відповідний одяг, розмовляти та розуміти українську мову тощо).

Емоційний компонент адаптації до навчально - виховного закладу полягає в загальному емоційному стані дитини під час перебування у дошкільному закладі [6].

Психологічна травма у дитини не виникає сама по собі, їй обов'язково передують якісь події. Почуті, а ніколи і побачені вибухи, вимушене чи спонтанне змінення місця проживання, навіть втрата улюбленої іграшки, подушки, ліжка, є для дитини дошкільного віку порушенням внутрішнього спокою, що часто призводить до психологічної травми. Тому, як правило, це порушення внутрішнього спокою має дуже сумні наслідки, якщо вча- сно не надано допомогу. Зміна місця соціального оточуючого середовища, зокрема, місця проживання, дитячого садочку, мовного середовища, тощо можуть викликати у дитини значний стрес. Як доведено науковцями, стреси перенесені у дитинстві є досить затяжними і можуть залишитись та вплинути на все іiї подальше життя.

Дітям, котрі пережили психологічну травму, досить важко зрозуміти, що сталося 3 ними. Це пов'язано, насамперед, з їх віковими особливостями, їм не вистачає соціальної, фізіологічної та психологічної зрілості. Дитина не в змозі повністю усвідомити зміст того, що відбувається, він просто запам'ятовує саму ситуацію, свої переживання в цю мить, особливо коли ця ситуація кардинально відрізняється від його буденного життя (під час військових дій в пам'ять врізається вереск гальм, свист падаючого снаряда, гул вертольотів, звуки ударів, вибуху, жар вогню тощо).

Інтенсивність переживань може бути занадто сильною для дитини, і вона стає дуже вразливою. Травмовані діти висловлюють свої, пов'язані з пережитим, почуття через поведінку. Так, у дітей дошкільного віку (від 4 до 7 років) відзначається прагнення до одноманітних ігор з використанням предметів, що мають відношення до психотравми: автомати, бойові машинки, ігри з агресією по відношенню до інших дітей, нецензурна лайка, тощо. Такі пережиті стресові ситуації залишають у дітей посттравматичні симптоми що включа- 
ють в себе зміни на фізіологічному, емоційному, когнітивному і поведінковому рівнях.

Так, до загальних посттравматичних симптомів, характерних для дитячого віку на фізіологічному рівні належать: різні порушення сну, часті пробудження під час сну, болі в животі, головні болі, що не мають фізичних причин, часте сечовипускання, особливо не контрольоване нічне, тремтіння, тики, посмикування, схильність картавити, тощо. [3,4]

Із психологічних це виникнення різних фобій: страх залишитись самому, спати без світла та одному та ін. Діти стають більш дратівливими, плаксивими, у них починає розвиватись депресія. Також у травмованих дітей погіршується концентрація уваги, вони стають неуважними, порушується пам'ять, діти стають забудькуватими, часто діти не можуть пригадати важливу персональну інформацію, особливо травматичного або стресового характеру. У дошкільному закладі такі діти показують агресію по відношенню до однолітків, стають більш впертими, гнівними, агресивними. Їх поведінка характеризується ворожістю $\mathrm{i}$ конфліктністю по відношенню до інших. У важких випадках ці симптоми можуть тривати протягом декількох місяців. Тому особливо важливо при таких симптомах у дитини тісно взаємодіяти із сім'єю дитини, для іiї адаптації у нове дошкільне середовище, щоб воно не ускладнило не тільки іiі стан, а і не вплинуло на та не викликало стреси у інших дітей. [4].

Психіка дитини дуже вразлива й потре- бує до себе дбайливого ставлення, адже малюк тільки починає пізнавати самого себе i світ навколо.

Не кожна дитина відкрита для відвертої розмови. Тому існують прийоми, що дають змогу практичному психологу поспілкуватися неначе «потайки», не турбуючи дитину, і одночасно виконуючи корекційну роботу. Враховуючі вікові особливості дітейдошкільників, для їх адаптації та інтеграції до нового дошкільного закладу можливо використовувати різні психотерапевтичні та ігрові практики. Однією із найбільш екологічної терапії $\epsilon$ арт-терапія - лікування мистецтвом. Арт-терапія - це ефективна корекція різних відхилень і порушень особистісного розвитку, найбільш м'який метод роботи 3 важкими проблемами як дитини, так і дорослого опираючись на здоровий потенціал особистості та внутрішні механізми саморегуляції і зцілення. Дитина може не говорити, може не визнавати свої проблеми, але при цьому ліпити, рухатись (танець), малювати, що значно допоможе як зняти психічне напруження, так і дізнатись психологу про внутрішню травму та проблему дитини. У роботі із дошкільниками корисно використовувати наступні техніки: малювання (монотипія, штрихування, каракулі, кляксографія, маранія, малюнок на склі), піскотерапія, танці, ізотерапія, музична, бібліотерапія, театр ( у тому числі і пальчиковий), тістопластика тощо.

Тому не зважаючи на тісний зв'язок 3 
лікувальною практикою, арт-терапія у багатьох випадках набуває переважно психотерапевтичної, соціалізуючої спрямованості.

Висновки та перспективи подальших досліджень. Враховуючи зазначене можна зробити висновок, що соціальна підтримка сімей не може бути зведена тільки до матеріальної, економічної допомоги (грошової або натуральної) сім'ям даної категорії або окремим їхнім членам. Саме комплексна співпраця науковців, психологів, соціальних працівників, соціального оточення та сім'ї допоможе підібрати та розробити індивідуальні психолого-педагогічні програми інтеграції дітей до нових умов проживання та навчання. Що у подальшому також позитивно вплине на інтеграцію дітей до нового соціального оточення та подальшу адаптацію їх до дошкільного закладу. А оволодіння вихователями, психологами ДНЗ методиками та психокорекційними практиками із застосування технологій психологопедагогічного супроводу дітей дошкільного віку сприятиме взаємодії з родинами дітей що забезпечить високий рівень психологічної допомоги і педагогічної підтримки дітей що перенесли травмуючи події та отримали стреси. Перспектива подальших досліджень полягає у необхідності розроблення методики індивідуального психолого-педагогічного супроводу що сприятиме успішній адаптації та реабілітації дітей - дошкільників із внутрішньо переміщених осіб та гармонізації їхнього розвитку.

\section{Перелік використаних джерел:}

1. Допомога дітям, постраждалим внаслідок воєнного конфлікту: Довідник вихователя дошкільного навчального закладу / Н.В. Пророк, С.А. Гончаренко, Л.О. Кондратенко та ін., за ред. Н. В. Пророк. - Слов'янськ: ПП «Канцлер», 2015. - 84 с.

2. Капська А. Й. Соціальна робота : [навчальний посібник] / А. Й. Капська. - Київ : Центр навчальної літератури, 2005. - 328 с.

3. Мельничук T. I. Актуальні проблеми соціалізація та ресоціалізації дітей в умовах сім’і усиновителів / Т. І. Мельничук // Актуальні проблеми психології : зб. наук. пр. Інституту психології ім. Г. С. Костюка НАПН України / за ред. С. Д. Максименка. - К. : Фенікс, 2014. - Т. 11, № 10. - C. 3-14.

4. Мельничук T. I. Соціально-психологічний супровід, як умова соціалізації усиновленої дитини в сім’ї / T. I. Мельничук // Наука і освіта : наук.-практ. журн. Південного наукового Центру НАПН України. - Одеса, 2013. - № 7/CXVII. - C. 178-183.

5. Сафонова Л. В. Содержание и методика психосоциальной работы : учеб. пособие для студ. высш. учеб. заведений / Л. В. Сафонова. - М. : Изд. центр «Академия», 2006. - 224 с.

6. Соиіально-педагогічна та психологічна допомога сім'ям 3 дітьми в період вій- ськового конфлікту : навчально-методичний посібник. - К. : Агентство “Україна". - 2015. - 165 с. C77-85 ISBN 978-966-137.

7. Психологічна допомога постраждалим внаслідок кризових травматичних подій: методичний посібник / З.Г. Кісарчук, Я.М. Омельченко, Г.П. Лазос, Л.І. Литвиненко... Царенко Л.Г.; за ред. З.Г. Кісарчук. - К.: ТОВ Видавництво "Логос". - 207 с).

8. Hárdi L. Psychotherapy and psychosocial care of torture survivor refugees in Hungary /L. Hárdi, A. Kroo // Torture Volume N 21. - November, 2011. - pp. 84-97.

9. Kenneth E. Miller. Rethinking a Familiar Model: Psychotherapy and the Mental Health of Refugees / Miller E. Kenneth // Journal of Contemporary Psychotherapy. - 
Vol. 29, No. 4,1999. - pp. 283- 306.

10. Kristal-Andersson B. Psychology of the refugee, the immigrant and their children: Development of a conceptual framework and application to psychotherapeutic related support work / B. Kristal-Andersson. - Department of Psychology, University of Lund, 2000. - 370p.

\section{References (Transliteration):}

1. Dopomoga dityam, postrazhdalim vnaslidok voennogo konfliktu: Dovidnik vihovatelya doshkilnogo navchalnogo zakladu / N.V. Prorok, S.A. Goncharenko, L.O. Kondratenko ta In., za red. N. V. Prorok. - Slov'yansk: PP «Kantsler», 2015. - 84 s.

2. Kapska A. Y. Sotsialna robota : [navchalniy posibnik] / A. Y. Kapska. - Kiyiv : Tsentr navchalnoyi literaturi, 2005. $-328 \mathrm{~s}$.

3. Melnichuk T. I. Aktualni problemi sotsializatsiya ta resotsializatsiyi ditey $\mathrm{v}$ umovah sIm'yi usinoviteliv / T. I. Melnichuk // Aktualni problemi psihologiyi : zb. nauk. pr. Institutu psihologyii im. G. S. Kostyuka NAPN Ukrayini / za red. S. D. Maksimenka. - K. : Feniks, 2014. T. 11, \# 10. - S. 3-14.

4. Melnichuk T. I. Sotsialno-psihologichniy suprovid, yak umova sotsIalizatsiyi usinovlenoyi ditini $\mathrm{v}$ sim'yi / T. I. Melnichuk // Nauka i osvita : nauk.-prakt. zhurn. PIvdennogo naukovogo Tsentru NAPN Ukrayini. - Odesa, 2013. - \# 7/CXVII. - S. 178-183.

5. Safonova L. V. Soderzhanie i metodika psihosotsialnoy rabotyi : ucheb. posobie dlya stud. vyissh. ucheb. zavedeniy / L. V. Safonova. - M. : Izd. tsentr «Akademiya», 2006. - 224 s.

6. Sotsialno-pedagogichna ta psihologichna dopomoga sIm'yam z ditmi v period viy- skovogo konfliktu : navchalno-metodichniy posibnik. - K. : Agentstvo "Ukrayina". 2015. - 165 s. S77-85 ISBN 978-966-137.

7. Psihologichna dopomoga postrazhdalim vnaslidok krizovih travmatichnih podiy: metodichniy posibnik / Z.G. Kisarchuk, Ya.M. Omelchenko, G.P. Lazos, L.I. Litvinenko... Tsarenko L.G.; za red. Z.G. Kisarchuk. - K.: TOV
Vidavnitstvo "Logos". - 207 s).

8. Hárdi L. Psychotherapy and psychosocial care of torture survivor refugees in Hungary /L. Hárdi, A. Kroo // Torture Volume N 21. — November, 2011. — pp. 84-97.

9. Kenneth E. Miller. Rethinking a Familiar Model: Psychotherapy and the Mental Health of Refugees / Miller E. Kenneth // Journal of Contemporary Psychotherapy. Vol. 29, No. 4,1999. - pp. 283- 306.

10. Kristal-Andersson B. Psychology of the refugee, the immigrant and their children: Development of a conceptual framework and application to psychotherapeutic related support work / B. Kristal-Andersson. - Department of Psychology, University of Lund, 2000. -370 p.

\section{Melnychuk Tetiana}

PhD in Psychology, Senior Research of the Laboratory of Organizational and Social Psychology in H. S. Kostyuk Institute of Psychology of the National Academy of Educational Sciences of Ukraine, Kyiv (Ukraine)

\section{Loseva Olga}

Psychologist, teacher of early development, Director of Children's Center 'ILMALINNA', Kyiv (Ukraine)

\section{PSYCHOLOGICAL - PEDAGOGICAL INTEGRATION OF CHILDREN FROM DOMESTICAL RELOCATED FAMILIES IN CHILDREN'S PRE-SCHOOL INSTITUTIONS}

\section{ABSTRACT}

The article analyses theoretical and practical analysis of the process of adaptation of children from internally displaced families to preschool institutions. The main ways of psychological and pedagogical interaction of educators, practical psychologists of social workers with families are outlined for providing them with special psychological and pedagogical help, revealing individual peculiarities of development of 
both positive and negative character of children of preschool age who have undergone stressful situations. Several psychological and pedagogical practices have been identified that have a positive effect on the adaptation and further integration of children from the families of internally displaced axes, to the new conditions of a preschool institution. It has been determined that the integrated cooperation of scientists, psychologists, social workers, social environment and family will help to find and develop individual psychological and pedagogical programs for integrating children into new living conditions and education. Also, the most important conditions for working with a child and her immediate social environment in a situation where the child is in the institution of social protection is the planning and forecasting of work. Contemporary views on the role of family education as a system of interrelated processes that teach and socialize a personality in childhood and most effectively help to integrate and socialize are considered. It has also been analyzed and highlighted that social support for families can not be reduced to material, economic assistance (monetary or natural) for families of this category or their individual members. It is a comprehensive social and psychological support that will positively influence the integration of preschoolers in educational institutions after traumatizing events. The most effective psychological and preventive and socializing practices for the integration of children into the new social and environmental environment are highlighted. It was estab- lished that the primary stage of working with a child is an initial and integrated assessment of the needs of the child and his social environment. The attention of social workers, social pedagogues and practical psychologists is focused on the correct formulation of the goal of rehabilitation of this category of children, which will provide an effective and effective approach to determining the necessary types of comprehensive social and psychological assistance to the family.

Key words: socio-psychological work, adaptation of children from internally displaced families, socialization of a child of preschool age, family education, integration of preschool children, socializing practices.

\section{Мельничук Татьяна Ивановна}

Кандидат психологических наук, старшый научний сотрудник Института психологи шимени Г.С. Костюка Начиональной академии педагогических наук Украинbl, город Киев (Украина)

\section{Лосева Ольга}

Психолог, педагог раннього розвитку, директор детского Центра «ILMALINNA», город Киев (Украина)

\section{ПСИХОЛОГО - ПЕДАГОГИЧЕСКАЯ \\ ИНТЕГРАЦИЯ ДЕТЕЙ В ДОШКОЛЬНЫХ УЧРЕЖДЕНИЯХ С СЕМЕЙ ВНУТРЕННЕ ПЕРЕМЕЩЕННЫХ ЛИЦ}

Аннотация. В статье проанализированы и представлены теоретический и практический анализ процесса интеграции и адаптации детей в дошкольные учреждения, с внутренне перемещенных семей. Рассмотрены 
и определены современные взгляды о роли влияния семейного воспитания как системы взаимосвязанных процессов, обучения и социализации личности ребенка в стрессовой ситуации. Выделены наиболее эффективные психолого профилактические и социализирующую практики для интеграции детей в новую соціально среду после перенесенных травмирующих событий. Сделаны выводы и сформирован перспективы дальнейших научных исследований.

Ключевые слова: социальнопсихологическая работа, адаптация детей с внутриперемищених семей, социализация ребенка дошкольного возраста, семейное воспитание, интеграция дошкольников, социализирующие практики. 